\title{
Subduction of young plates: A case of the Philippine Sea plate beneath the Chugoku region, Japan
}

\author{
Ichiro Nakanishi $^{1}$, Yukiko Kinoshita ${ }^{1}$, and Katsumi Miura ${ }^{2}$ \\ ${ }^{1}$ Department of Geophysics, Kyoto University, Kyoto 606-8502, Japan \\ ${ }^{2}$ Hiroshima Seismological Observatory, Earthquake Research Institute, University of Tokyo, Hiroshima 739-1731, Japan
}

(Received March 16, 2000; Revised October 1, 2001; Accepted October 5, 2001)

\begin{abstract}
An analysis of seismic waves from regional microearthquake networks shows that the seismic leading edge of the Philippine Sea plate may have reached the uppermost mantle beneath the southern to central part of the western Chugoku region, Japan. The epicenters are located close to the volcanic front in the region. The most possible cause of the very low seismicity may be the initiation of melting of the Philippine Sea plate.
\end{abstract}

\section{Introduction}

It can be inferred that young subducted plates show clear physical and chemical processes associated with subduction as compared with old subducted plates. We can expect that a process like assimilation of subducted slab into surrounding mantle is observed in seismicity of subducted plates, their shapes, or relation between subducted plates and volcanism. The Philippine Sea plate, the subduction of which is studied here, is young and involves a dead spreading axis normal to the trench (Kobayashi and Nakada, 1978).

The Philippine Sea plate subducts under the Eurasian and North American plates. The subduction may be divided into eastern and southwestern parts by the Kyushu-Palau Ridge. In the eastern part, the Shikoku Basin subducts along the Nankai Trough beneath the Shikoku Island. In the southwestern part, the Western Philippine Basin subducts along the Ryukyu Trench beneath the Kyushu and Ryukyu Islands. The Shikoku Basin is about 30 to $20 \mathrm{Ma}$ (Kobayashi and Nakada, 1978) or about 25 to 15 Ma (Shih, 1980a), which is much younger than the Western Philippine Basin of about 59 to $26 \mathrm{Ma}$ (Shih, 1980b). The Shikoku Basin is also characterized by a dead spreading axis with N-S trend located near the central part of the Basin (Kobayashi and Nakada, 1978).

The subduction of the eastern part of the Philippine Sea plate beneath the Shikoku and Chugoku regions in Southwestern Japan is characterized by several geological and geophysical observational results (Shiono, 1988; Uto and Tatsumi, 1996): 1) The Nankai Trough is much shallower than the Japan Trench. 2) No intermediate and deep earthquakes occur in the mantle. 3) There is no volcano whose activity is supported by historical document. However, the last activities of Daisen and Sambe volcanoes are dated 17 Ka (Saji et al., 1975) and 3.7 Ka (Matsui and Inoue, 1971), respectively. 4) The thermal structure of the crust is anoma-

Copy right (C) The Society of Geomagnetism and Earth, Planetary and Space Sciences (SGEPSS); The Seismological Society of Japan; The Volcanological Society of Japan; The Geodetic Society of Japan; The Japanese Society for Planetary Sciences. lous. Similar anomalies have also been reported for the Cascade Range of northern California (McKenzie and Julian, 1971; Fowler, 1990), Peru and central Chile (Isacks and Barazangi, 1977).

Mizoue (1976) investigated the distribution of subcrustal earthquakes beneath southwestern Japan, and made a contour map of the seismic plane (Fig. 1). Since then, this map had served as a standard in scientific discussions on solid earth of the southwestern Japanese Islands. Yamazaki and Ooida (1985) presented a more detailed contour map for the Philippine Sea plate, but the subcrustal seismicity beneath the Chugoku region was still unknown. Miura et al. (1991) studied the subcrustal seismicity in the western part of the Seto Inland Sea (Seto Naikai) and surrounding regions. They found a small number of earthquakes with depths of about 50 to $70 \mathrm{~km}$ beneath the central part of Hiroshima prefecture. They suggest the extension of the leading edge of the seismic Philippine Sea plate down to the uppermost mantle beneath the Seto Inland Sea side of Hiroshima prefecture $\left(34.4^{\circ} \mathrm{N}\right)$.

Nakanishi (1980) has analyzed the ScSp phase observed in the western Chugoku region and has suggested that the leading edge of the Philippine Sea plate descending from the Nankai Trough may have reached the upper mantle beneath the Chugoku region. Nishi and Oda (1994) have analyzed the ScSp phase observed at Shibukawa seismological observatory of Okayama University, which is located in the southern part of the eastern Chugoku region. They have suggested that the Philippine Sea plate subducts with a very shallow angle beneath there. Hirahara (1981), using a threedimensional inversion of travel-time data, has suggested the existence of a high velocity zone in the uppermost mantle beneath the Chugoku region. This high velocity zone is considered as the Philippine Sea plate suggested by Nakanishi (1980). The existence of the high velocity zone has been supported by recent studies of Oda et al. (1990) and Yamane et al. (2000). Thus it is very likely that the Philippine Sea plate exists in the uppermost mantle beneath the Chugoku 


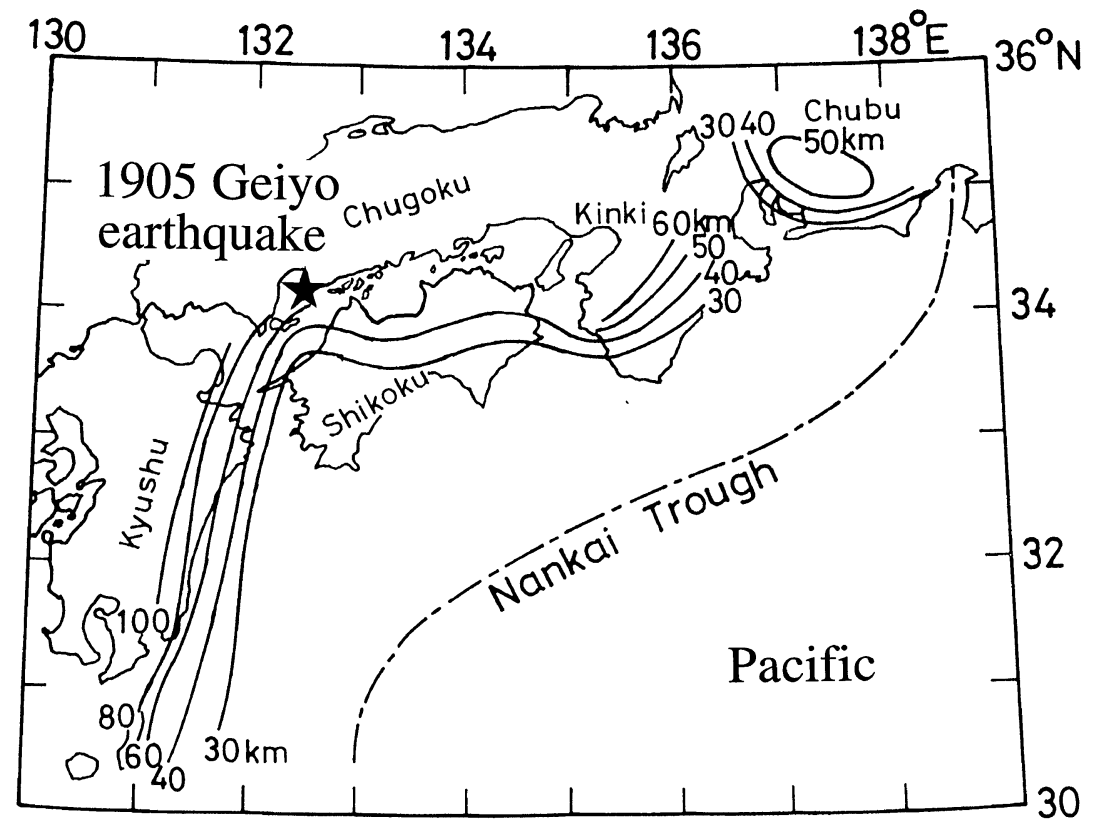

Fig. 1. Contour map of the seismic plane of subcrustal earthquakes due to the subduction of the Philippine Sea plate (Mizoue, 1976). The epicenter of the 1905 Geiyo earthquake is indicated by the solid star. The depths of earthquakes in the Geiyo area and the central to northern Shikoku region are systematically larger in this figure than those in Figs. 3 and 4, and in the contour maps of recent studies (e.g., Yamazaki and Ooida, 1985; Miura et al., 1991).

region.

Kinoshita and Nakanishi (1997) have shown that small subcrustal earthquakes are located beneath the Seto Inland Sea and the southern part of the Chugoku region by examining the data sets from Japan Meteorological Agency (JMA) and Japan University Network Earthquake Catalog (JUNEC). They have suggested that subcrustal earthquakes occur beneath the southern part of Chugoku region due to the subduction of the Philippine Sea plate.

Kinoshita and Nakanishi (1997) have used hypocentral data reported in the catalogs of JMA and JUNEC. Reexamination of original seismograms from microearthquake observations may provide us with the northern extension of the leading edge of the subcrustal seismicity due to the subduction of the Philippine Sea plate. The aim of the present study is to investigate the locations, magnitudes and focal mechanisms of subcrustal earthquakes beneath the Chugoku region by analyzing the seismograms recorded by microearthquake observation networks.

\section{Data and Analysis}

We analyze the original seismograms recorded by the networks of Hiroshima Seismological Observatory of Earthquake Research Institute, University of Tokyo, and seismological stations of Kochi and Kyoto Universities (Fig. 2). The observation period ranges from October 5, 1983 to September 24, 1993.

All the earthquakes that we analyze have been located by routine location process of the Hiroshima Seismological Observatory. We relocate the earthquakes with epicentral latitudes higher than $34^{\circ} \mathrm{N}$, depths deeper than $35 \mathrm{~km}$, and local magnitudes larger than 1.5 , because the principal aim of this study is to detect the northern end of the subcrustal

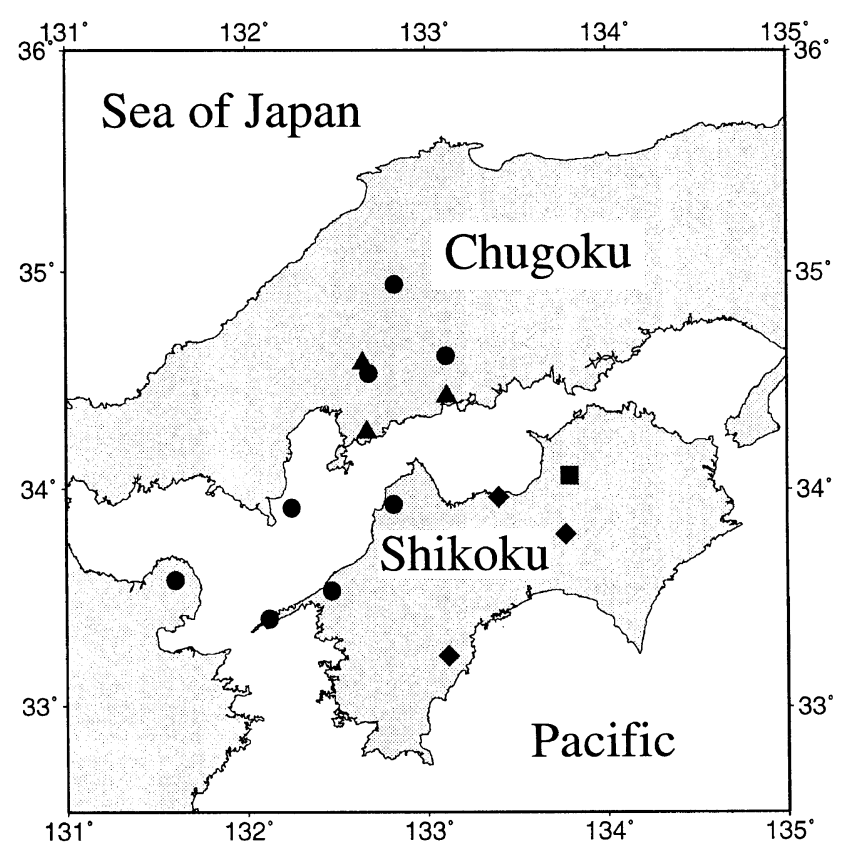

Fig. 2. Distribution of the seismological stations used in this study. The permanent and temporary stations of Hiroshima Seismological Observatory are indicated by the solid circles and solid triangle, respectively. The stations of Kochi University and Kyoto University are indicated by the solid diamonds and solid square, respectively.

seismicity due to the subduction of the Philippine Sea plate beneath the Chugoku region. The earthquake relocation is made by using a least-squares method. The arrival times of both direct $P$ - and direct $S$-waves are read by the authors and JMA travel time tables (Hamada, 1984) are used. 


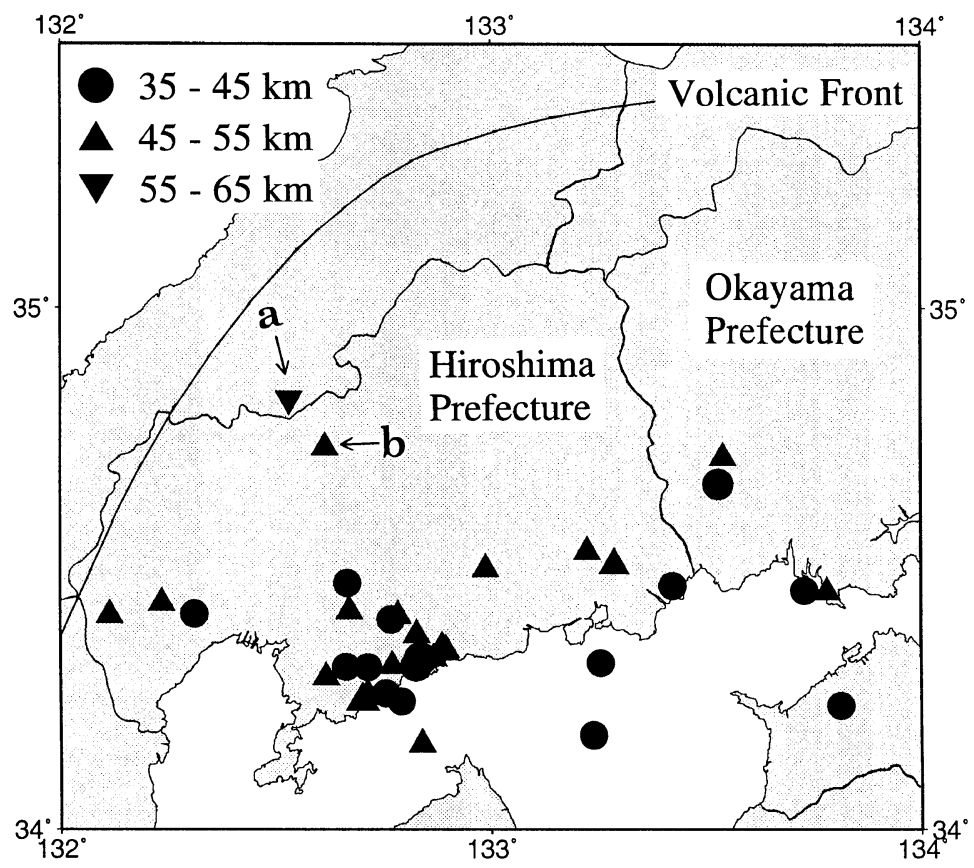

Fig. 3. Distribution of the epicenters relocated in this study for the period during October 5,1983 to September 24 , 1993 . The solid circles indicate the hypocentral depths of 35-45 km, the solid triangles $45-55 \mathrm{~km}$, and the inverted solid triangles 55-65 km. Hypocenters deeper than $65 \mathrm{~km}$ are not found. The locations of the earthquakes ' $a$ ' and ' $b$ ' are discussed in text. The solid line indicates the Quaternary volcanic front.

\section{Result}

Figure 3 shows the epicentral distribution of the earthquakes relocated in this study. Figure 4 shows the vertical cross-sections of the hypocentral locations. The direction of $\mathrm{N} 30^{\circ} \mathrm{W}$ of the cross-sections for the areas $\mathrm{A}-\mathrm{A}^{\prime}$ and $\mathrm{B}-\mathrm{B}^{\prime}$ is perpendicular to the strike of the Nankai Trough.

Two earthquakes are located in the central to northern area of the Chugoku region. These earthquakes are indicated by ' $a$ ' and ' $b$ ' in Figs. 3 and 4. The location errors of these earthquakes are $1.4 \mathrm{~km}$ (latitude), $2.3 \mathrm{~km}$ (longitude) and $1.8 \mathrm{~km}$ (depth) for ' $\mathrm{a}$ ', and $6.3 \mathrm{~km}, 7.4 \mathrm{~km}$ and $12.8 \mathrm{~km}$ for ' $b$ '.

The source mechanisms of the subcrustal earthquakes with relatively large magnitudes of 3.6 to 4.3 are determined from the polarities of $P$-wave first motions from the data of JMA and Hiroshima Seismological Observatory (Fig. 5). We have determined the source mechanisms of five earthquakes. It can be seen in the figure that the $T$ axes of the earthquakes except October 30, 1987 are oriented roughly parallel to the isoseismic contours near the northern Shikoku region (Fig. 1 of the present paper (Mizoue, 1976); Yamazaki and Ooida, 1985). The direction of isoseismic contour ranges from $\mathrm{N} 105^{\circ} \mathrm{E}$ in western Shikoku to $\mathrm{N} 75^{\circ} \mathrm{E}$ in eastern Shikoku (Fig. 1). The directions of the $T$-axes of the 4 earthquakes range from $\mathrm{N} 110^{\circ} \mathrm{E}$ (October 5,1983 ) to $\mathrm{N} 75^{\circ} \mathrm{E}$ (May 13, 1984) (Fig. 5). This observation is similar to that for subcrustal earthquakes beneath the Shikoku Islands (Shiono, 1977), which supports the idea that the earthquakes in Fig. 5 occur in the subducting Philippine Sea plate beneath the Chugoku region.

\section{Discussions}

Seismicity. The result of the present study suggests that the seismic part of the Philippine Sea plate has reached the uppermost mantle beneath the southern to central part of the western Chugoku region (Fig. 4).

Kinoshita and Nakanishi (1997) and the present study show that there occur earthquakes associated with the subducting Philippine Sea plate beneath the Seto Inland Sea and the southern to central part of the Chugoku region. These studies also show that the seismicity of the uppermost mantle of the region is very low as compared with that of the Shikoku region. However, a large earthquake occurred on June 2, 1905 in the southern part of the western Chugoku region (Aki-Nada or Geiyo area). This earthquake caused 11 deaths and 64 total collapses of buildings. The depths and the magnitudes estimated range 40 to $100 \mathrm{~km}$ and 6.7 to 7.9, respectively (Miyagawa et al., 1998a, b). In most contour maps of seismic plane for this region (Mizoue, 1976; Yamazaki and Ooida, 1985; Shiono, 1988), the isoseismic contour for the Philippine Sea plate does not reach the epicentral area of this earthquake, except in the contour map suggested by Miura et al. (1991).

In the Geiyo area, large earthquakes occurred with an approximately constant interval of about 40 to 50 years in 1649 (Keian 2, M 7.0), 1686 (Jyokyo 2, M 7.0 7.4), 1733 (Kyoho 18, M 6.6), 1812 (Bunka 9, M 7.0), 1857 (Ansei 4, M 7 1/4), 1905 (Meiji 38, M 7 1/4), and 1949 (Shyowa 24, M 6.2) (Hatori, 1989; Usami, 1996; Nakanishi and Nakamura, 2000). A moderate earthquake with a JMA magnitude of 6.7 occurred at 6 h $28 \mathrm{~m}$ (GMT) on March 24, 2001 (Heisei 13). The earthquake struck the Chugoku and Shikoku regions and caused 2 deaths and 69 total collapes of buildings (June 4,2001$)$. Hypocenter location $\left(34.1^{\circ} \mathrm{N}, 132.7^{\circ} \mathrm{E}, 51\right.$ $\mathrm{km}$ ) and CMT solution are seen in web pages of DPRI (Disaster Prevention Research Institute, Kyoto University) and 

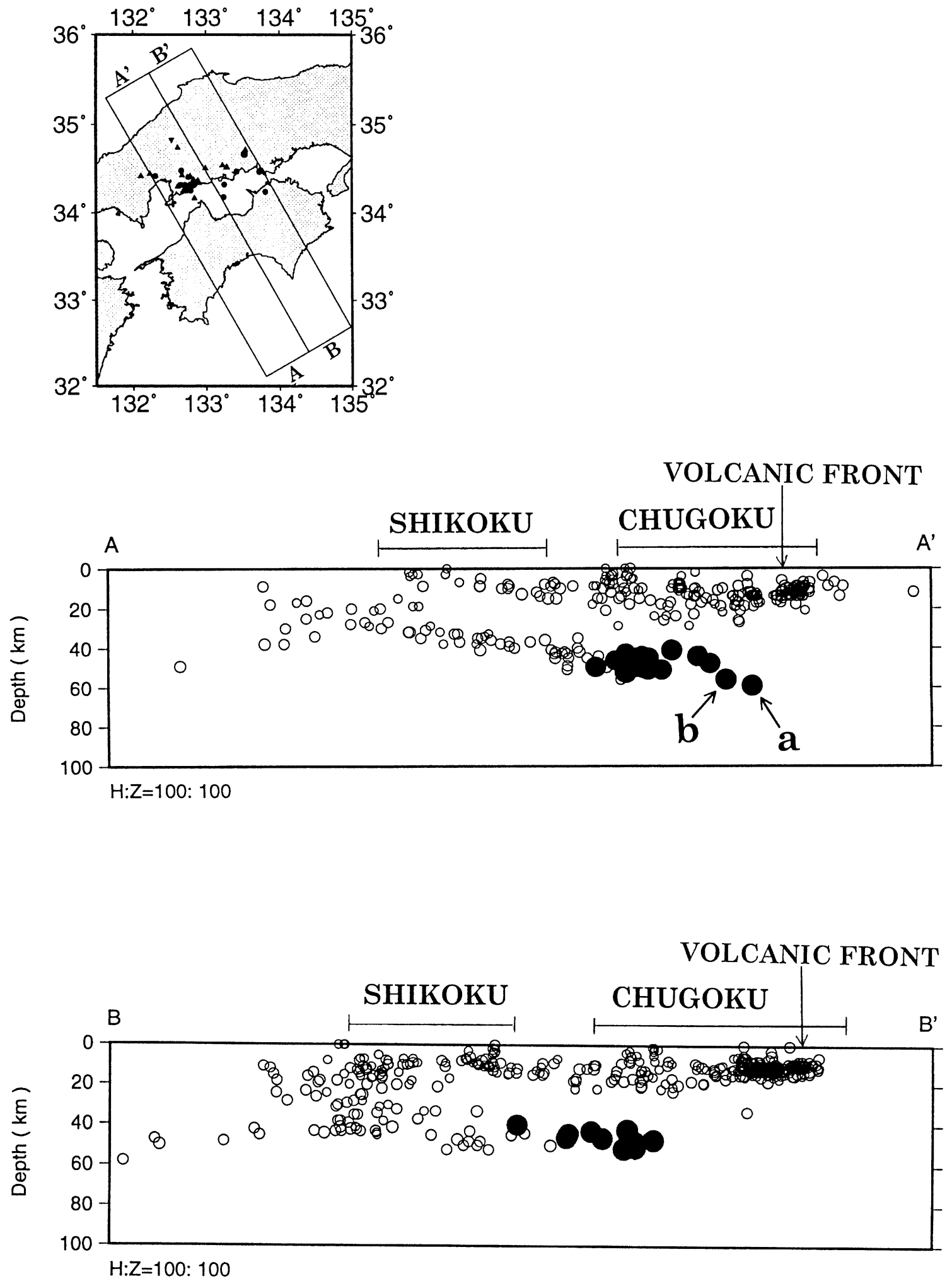

Fig. 4. Vertical cross-sections in the direction of $\mathrm{N} 30^{\circ} \mathrm{W}$ of the hypocentral locations for the western part of the Chugoku region and the central part of the Shikoku region. The open circles indicate the hypocenters located by JMA for the period of October 1, 1994 to May 13, 1996. The solid circles indicate the hypocenters relocated in this study for the period of October 5, 1983 to September 24, 1993.

NIED (National Research Institute for Earth Science and Disaster Prevention). Thus detailed seismological study of this area is still important for the prevention of disasters due to earthquakes in the Philippine Sea plate.

Source mechanism. As mentioned above, Fig. 5 shows that the $T$-axes of the subcrustal earthquakes except October 30, 1987 in the southern Chugoku region are oriented parallel to the isoseismic contours near the northern Shikoku region (Fig. 1). The same orientation of the $T$-axes of subcrustal earthquakes is found in subcrustal earthquakes in 




Fig. 5. Focal mechanisms of the five subcrustal earthquakes. The equal-areal projection of the lower hemisphere is used. The tension and compression axes are indicated by ' $T$ ' and ' $P$ ', respectively.

the Shikoku, Kii (Shiono, 1977), and Tokai (Ukawa, 1982) regions. Therefore, the stress state within the subducting Philippine Sea plate beneath the southern Chugoku region may be close to the stress state of the Philippine Sea plate beneath those regions. Figure 5 shows that one of the two nodal planes is steep in all of the five earthquakes. We might be able to infer that the fault plane of the 1905 earthquake is also steep. Preliminary analysis of old seismograms of this earthquake (Miyagawa et al., 1998a, b) shows that the least-squares fit to the seismograms is obtained for a normal fault mechanism solution (strike $=142^{\circ}$, dip $=40^{\circ}$, rake $=-34^{\circ}$ ). The 2001 Geiyo earthquake and its aftershocks provide us with supporting evidence for the above discussion. The CMT solution of the main shock determined by NIED is $\left(M_{W}=6.8\right.$, strike $=188^{\circ}$, dip $=59^{\circ}$, rake $=-56^{\circ}$ ). The $T$-axes of the main shock and the aftershocks are oriented to ENE-WSW to E-W directions. The aftershock distribution determined by DPRI show an approximately N-S trend.

Volcanoes. Volcanism in Northeastern Japan is explained by melting of the mantle wedge overlying the subducting Pacific plate. However, the subduction of the Philippine Sea plate beneath Southwestern Japan occurs at a shallow angle and it seems difficult to explain the Quaternary volcanism in this region by melting of very narrow or nonexistent mantle wedge. Defant and Drummond (1990) suggest the idea of slab melting to explain the chemical composition of magmas termed 'adakites' by partial melting of young subducted slab, and show that subducting plate younger than $25 \mathrm{Ma}$ is required for the slab melting.
Morris (1995) shows that unusual chemistry of volcanic rocks from Sambe and Daisen volcanoes, which are similar to adakites in chemistry, and the aseismicity in the uppermost mantle beneath this region, can be explained by melting of the Philippine Sea plate at depths of about 75 to 100 $\mathrm{km}$ beneath the Quaternary volcanic front of the Chugoku region. The results of the present study, Nakanishi (1980), and Nakanishi et al. (1981) are consistent with his model. Recent tomographic studies by Yamane et al. (2000) and Nakanishi and Honda (2000) suggest that high-velocity extension of the subducting Philippine Sea plate is located beneath the volcanic front of the Chugoku region. The initiation of melting of the Philippine Sea plate can explain the very low seismicity of high-velocity extension of the Philippine Sea plate.

Tectonics. Shiono (1992) suggests a model which explains the relation between the location of the leading edge of the Philippine Sea plate and the Quaternary activity of the Median Tectonic Line (Okada, 1980). His model requires that the plate is not located in the mantle beneath the southern part of the eastern Hiroshima and western Okayama (Fig. 3). The occurrence of subcrustal earthquakes beneath these areas is inconsistent with his model.

The Chugoku region is underlain by the Philippine Sea plate and the Pacific plate. Thus we have to consider the two subducting plates to explain very complex tectonic and petrological features of the Chugoku region. Further discussion on these problems is beyond the scope of the present paper. 


\section{Conclusion}

The result of the present study suggests that the seismic leading edge of the Philippine Sea plate has reached the uppermost mantle beneath the southern to central part of the western Chugoku region, Japan. The most possible cause of the very low seismicity may be the initiation of melting of the Philippine Sea plate.

Acknowledgments. The JMA data during the period from October 1, 1994 to May 13, 1996 were made available to us by courtesy of A. Kuroiso of Osaka Meteorological Observatory, Japan. This study was supported by Kurata Science Foundation.

\section{References}

Defant, M. J. and M. S. Drummond, Derivation of some modern arc magmas by melting of young subducted lithosphere, Nature, 347, 662-665, 1990.

DPRI, http: / / www .rcep.dpri . kyoto-u.ac.jp/.

Fowler, C. M. R., The Solid Earth: An Introduction to Global Geophysics, Cambridge Univ. Press, 1990.

Hamada, N., Re-examination of travel time tables for local earthquakes, Pap. Meteor. Geophys., 35, 109-167, 1984 (in Japanese with English abstract, tables, and figures).

Hatori, T., Magnitudes of the historical Akinada (Set Inland Sea) earthquakes and possibility of tsunami generation, Historical Earthquakes, 5, 99-109, 1989 (in Japanese with English abstract, table, and figures).

Hirahara, K., Three-dimensional seismic structure beneath southwest Japan: The subducting Philippine Sea plate, Tectonophys., 79, 1-44, 1981.

Isacks, B. L. and M. Barazangi, Geometry of Benioff zones: Lateral segmentation and downwards bending of the subducted lithosphere, in Island Arcs, Deep Sea Trenches and Back-Arc Basins, edited by M. Talwani and W. C. Pitman, III, Am. Geophys. Union, Washington, D.C., pp. 99-114, 1977

Kinoshita, Y. and I. Nakanishi, Subcrustal seismicity beneath the southern part of the Chugoku region, Japan, J. Phys. Earth, 45, 307-312, 1997.

Kobayashi, K. and M. Nakada, Magnetic anomalies and tectonic evolution of the Shikoku inter-arc basin, J. Phys. Earth, 26 (Suppl.), s392-s402, 1978.

Matsui, S. and T. Inoue, Pyroclastics and their stratigaphy from Volc. Sambe, Chikyu Kagaku, 25, 147-163, 1971 (in Japanese).

McKenzie, D. and B. Julian, Puget Sound, Washington, earthquake and the mantle structure beneath the northwestern United States, Bull. Geol. Soc. Am., 82, 3519-3524, 1971.

Miura, K., T. Tsukuda, R. Miura, Y. Inoue, and S. Asano, Deep seismic zone in the western part of the Seto Naikai (Seto Inland Sea) and its surrounding regions, Southwestern Japan, Bull. Earthq. Res. Inst., Univ. Tokyo, 66, 553-570, 1991 (in Japanese with English abstract, table, and figures).

Miyagawa, K., K. Miura, I. Nakanishi, and S. Tanaka, Seismograms of the 1905 Geiyo earthquake, Historical Earthquakes, 13, 89-97, 1998a (in Japanese).

Miyagawa, K., K. Miura, I. Nakanishi, and S. Tanaka, The 1905 Geiyo earthquake $(\mathrm{M}=7.3)$ recorded by the Omori seismometers and the digitization of the records, J. Seism. Soc. Japan, 51, 113-121, 1998b (in Japanese with English abstract, tables, and figures).

Mizoue, M., Some remarks on the characteristics of subcrustal earthquake activities, Proc. Natl. Symp. Earthquake Prediction in Japan, 97-105,
1976 (in Japanese).

Morris, P. A., Slab melting as an explanation of Quaternary volcanism and aseismicity in southwest Japan, Geology, 23, 395-398, 1995.

Nakanishi, I., Precursors to ScS phases and dipping interface in the upper mantle beneath southwest Japan, Tectonophys., 69, 1-35, 1980.

Nakanishi, I. and S. Honda, Location of the leading edge of the Philippine Sea plate beneath SW Japan: High-resolution P-wave tomography, Programme and Abstracts, Seism. Soc. Japan, 2000 Fall Meeting, B53, 2000 (in Japanese).

Nakanishi, I. and M. Nakamura, Historical earthquakes of the Philippine Sea plate beneath SW Japan as inferred from the recent activity of the plate earthquakes, Programme and Abstracts, Seism. Soc. Japan, 2000 Fall Meeting, B56, 2000 (in Japanese).

Nakanishi, I., K. Suyehiro, and T. Yokota, Regional variations of amplitudes of ScSp phases observed in the Japanese Islands, Geophys. J. Roy. Astr. Soc., 67, 615-634, 1981.

NIED, http: / / argent.geo.bosai.go.jp/.

Nishi, M. and H. Oda, ScSp phase observed on the coast of the Seto Inland Sea, Earth Science Report, Okayama University, 1, 19-26, 1994 (in Japanese with English abstract, table, and figures).

Oda, H., T. Tanaka, and K. Seya, Subducting oceanic crust on the Philippine Sea plate in Southwest Japan, Tectonophys., 172, 175-189, 1990.

Okada, A., Quaternary faulting along the Median Tectonic Line of Southwest Japan, Mem. Geol. Soc. Japan, No. 18, 79-108, 1980.

Saji, K., K. Tazaki, S. Akagi, and H. Asada, Stratigraphy of the Daisen tephra-Application of mineralogical and morphological studies, Chikyu Kagaku, 29, 199-210, 1975 (in Japanese).

Shih, T. C., Magnetic lineations in the Shikoku Basin, Initial Reports of the Deep-Sea Drilling Project, 58, U.S. Goverment Printing Office, Washington D. C., 783-788, 1980a.

Shih, T. C., Marine magnetic anomalies from the western Philippine Sea: Implications for the evolution of marginal basins, $A G U$ Geophys. Monogr., 23, 19-33, 1980b.

Shiono, K., Focal mechanism of major earthquakes in southwest Japan and their tectonic significance, J. Phys. Earth, 25, 1-26, 1977.

Shiono, K., Seismicity of the SW Japan arc-subduction of the young Shikoku Basin, Modern Geology, 12, 449-464, 1988.

Shiono, K., Frontal shape of subducting plate along the Nankai Trough and recent activity of the Median Tectonic Line, Mem. Geol. Soc. Japan, No. 40, 197-204, 1992 (in Japanese with English abstract).

Ukawa, M., Lateral stretching of the Philippine Sea plate subducting along the Nankai-Suruga Trough, Tectonics, 1, 543-571, 1982.

Usami, T., Materials for Comprehensive List of Destructive Earthquakes in Japan, 416-1995, Revised and Enlarged Edition, Univ. Tokyo Press, Tokyo, 1996 (in Japanese).

Uto, K. and Y. Tatsumi, Quaternary volcanism of the Japanese Islands, The Island Arc, 5, 250-261, 1996.

Yamane, T., I. Nakanishi, and S.-I. Kamiya, P-wave velocity structure of the Philippine Sea plate subducting from the Nankai trough and its relation with seismicity and volcanism in Southwestern and Central Japan, Bull. Earthq. Res. Inst., Univ. Tokyo, 75, 335-374, 2000 (in Japanese with English abstract and figures).

Yamazaki, F. and T. Ooida, Configuration of subducted Philippine Sea plate beneath the Chubu district, central Japan, J. Seism. Soc. Japan, 38, 193 201, 1985 (in Japanese with English abstract, tables, and figures).

I. Nakanishi (e-mail: ichiro@kugi.kyoto-u.ac.jp), Y. Kinoshita, and K. Miura 